\title{
THE 1935 AMENDMENTS OF THE RAILROAD BANKRUPTCY LAW *
}

\author{
$T^{N}$ I933, Congress enacted a comprehensive bankruptcy statute \\ applying to railroads engaged in interstate commerce. ${ }^{1}$ In \\ I935, in light of the experience with the administration of the stat- \\ ute, the Federal Coordinator of Transportation ${ }^{2}$ recommended \\ extensive amendments. ${ }^{3}$ Congress enacted an amended statute on \\ August 27, I $935^{4}$ in general accordance with the Coordinator's
}

* The amendments to the Railroad Bankruptcy Act passed by Congress in I935, Act of Aug. 27, I935, c. 774, 49 STAT. 9II, II U. S. C. A. § 205 (Supp. I935), were largely based upon a statute recommended by Joseph B. Eastman, Federal Coordinator of Transportation, and prepared by the writers of this article. - ED.

1 Act of March 3, I933, c. 204, 47 STAT. I474, II U. S. C. \$ 205 (I935).

2 The provisions of the Emergency Railroad Transportation Act of 1933 require the Federal Coordinator of Transportation to submit recommendations to Congress as to future legislation to improve transportation conditions throughout the country. 48 STAT. 216,49 U. S. C. $\$ 263$ (I935).

3 See Report of Coordinator, H. R. Doc. No. 89, 74th Cong., Ist Sess. (I935). For the Coordinator's recommendations and the bill proposed by him, see id. at 35, 100, 229. This bill was introduced in the Senate as S. 1634 and, with certain modifications, in the House as H. R. 6249. The Interstate Commerce Commission had made general recommendations of similar amendments. 48 ANN. REP. INTERstate Comamerce Comar. (I934) I7-I9. The President endorsed the proposed legislation in his message of June 7,1935 .

4 Act of Aug. 27, I935, c. 774, 49 Stat. 9II, II U. S. C. A. § 205 (Supp. I935). The bill, H. R. 8587 , received thorough consideration by the House Committee on the Judiciary at hearings at which there was a full representation of the various interests and as a result of which the Committee made various changes in the bill as proposed by the Coordinator. There were appearances in the hearings before the House Committee by the Federal Coordinator and representatives of the Interstate Commerce Commission, the Reconstruction Finance Corporation, the 2x standard railroad labor organizations, an association of the major life insurance companies, the National Association of Mutual Savings Banks, the Association of American Railroads, the American Short Line Railroad Association, certain independent committees of stockholders and bondholders, and other individuals. A transcript of these hearings was printed as Hearings before Committee on Judiciary on $H . R$. 6249 , 74th Cong., Ist Sess. (I935). These hearings comprised eight days, and the committee then considered the bill in executive session over a period of four weeks. On June 2I, I935, the House committee reported out the bill. See H. R. Rep. No. I283, 74th Cong., Ist Sess. (Committee on Judiciary, I935). The bill was passed by the House on Aug. I5, I935. 79 CoNG. REc. I3302-09. In the Senate, the bill was referred to the Committee on Interstate Commerce. It reported the bill 
recommendations, leaving untouched hardly a sentence of the original Act. The purpose of this article is to consider certain of the more important amendments.

Under the orthodox equity procedure in effect before the enactment of Section 77, railroad reorganizations had been responsible for some of the worst pages in the history of the administration of our law. ${ }^{5}$ There was general dissatisfaction with the conditions. ${ }^{\circ}$ Although it is not easy to appraise the situation, and the experts, most of whom are not disinterested, disagree as to the facts and causes, the general outlines are fairly clear. These conditions are not only significant as indicating a past from which it is desirable to escape through a reform to be accomplished by such legislation as Section 77. They indicate present dangers. For, if a reorganization is not effected in bankruptcy, it is the duty of the court to dismiss the proceedings, and the equity processes will then ensue. Further, many railroad reorganizations are now pending in the equity courts. ${ }^{7}$

favorably Aug. I6, 1935, after consideration in executive session. See SEN. REp. No. 1336, 74th Cong., Ist Sess. (Committee on Interstate Commerce, 1935). The bill was passed by the Senate Aug. 20, 1935, with a minor amendment which was accepted in the House. 79 Conc. REc. 13764-69. There was no opposition to the bill on the floor of either house. On the floor of the Senate, the bill was supported by Senator Wheeler, and by Senator Hastings of Delaware of the Republican minority, Senator Hastings having sponsored the original $\S 77$ in the Senate in 1933.

5 See testimony of Mr. Eastman, Hearings before Committee on Judiciary on $H . R .6249$, 74th Cong., Ist Sess. (1935) I4, 23. The whole subject of railroad financing is now under a comprehensive investigation by the Senate Committee on Interstate and Foreign Commerce.

- See Spring, Upset Prices in Corporate Reorganization (I9I9) 32 Harv. L. Rev. 489; Dodd, Reorganization through Bankruptcy: A Remedy for What? (I935) 48 id. Iroo; Swaine, Corporate Reorganization under the Federal Bankruptcy Power (I933) I9 VA. L. Rev. 3r7, 333; Frank, Some Realistic Reflections on Some Aspects of Corporate Reorganization (1933) I9 id. 54I; Lowenthal, The Investor Pays (I933); Moulton, The American Transportatton Problear (I933) 349; 3 A Sharfacan, The Interstate Comamerce Comianssion (1935) 577.

7 As of March I, 1936, 92 railroad reorganizations were pending, of which 44 were under $\$ 77$, and 48 in the equity courts. The mileage of the roads under reorganization under $\$ 77$ totaled 56,972 miles. The mileage of the roads under equity receiverships totaled 17,950 miles. Practically all of the larger properties are in bankruptcy proceedings. A great part of the large number of small reorganizations pending in equity consists of suits started before $\S 77$ was enacted. Since its enactment very few proceedings in equity have been instituted. The Commission on April 7, I936 issued its first orders approving reorganization plans in $\S 77$ proceedings. Copper Range R. R. Reorganization, Finance Docket No. Io,8ro; Chicago, S. S. \& S. B. R. R. Reorganization. Finance Docket No. xo,165. 
It seems quite generally agreed that the procedure in equity, suitable for the reorganization of the ordinary private industrial companies, has proved inadequate for the reorganization of corporate systems of the magnitude and complexity of the typical railroad, operating as a common carrier in as many as a dozen states. ${ }^{8}$ These reorganizations have proceeded with no proper supervision by the Interstate Commerce Commission. Its function has been merely to approve the issuance of the securities after the reorganization plan has been approved by the court, an interposition too late, and a function too limited, to be effective. ${ }^{9}$ The courts have been similarly handicapped, in that their examination of the plan has been held in connection with the sale of the property, at a stage so late in the proceedings that they have been naturally reluctant to break down the reorganization effort, especially where the plan is approved by substantial interests. ${ }^{10}$ Further, the judges have frequently been unfamiliar with such complex financial problems, or unduly impressed by the size of the operation, and therefore have not had enough confidence to substitute their judgment for the judgment of the professional reorganizers, and to assume the responsibility involved in rejecting what they have proposed. ${ }^{11}$

8 The complexity of a typical railroad reorganization is shown by the following data concerning the pending Missouri Pacific reorganization, the figures being approximate figures: debtor corporations before the court, 8; corporations involved including wholly owned subsidiaries and leased lines, not all before the court, $3 \mathrm{I}$; miles of line, IO,200; states in which operated, II; total capitalization, approximately $\$ 700,000,000$; bondholders, 50,000; stockholders, I0,000; general unsecured creditors, between 2000 and 3000 ; different kinds of stock, 33; different kinds of indebtedness, 84 ; mortgages protecting bonds in the hands of the public, I7; equipment trusts, II.

9 "The Commission has not rejected outright any of the forty odd plans submitted to it since I920, though in a few cases it has required minor changes." Moviton, op. cit. supra note 6, at 325. For discussion of function and action of the Commission, see Note (I93I) 44 HARv. L. Rev. 838.

10 See Frank, supra note 6, at 565, 7II, 7 12 ; MoulToN, op. cit. supra note 6, at 353 .

11 The federal judges have been disinclined to examine reorganization plans thoroughly. 79 CoNG. REc. 13764 (1935). The Commission attempted to intercede in the reorganization case of an important western line, in the effort to secure a scrutiny of the plan by a federal judge recognized as having had wide experience with railroad reorganizations. He told the Commission that only younger or less experienced judges could be expected to accede to such a request, and that in the light of his experience with these cases, if the plan were approved by a sufficient part of the 
The result has been that the reorganization accomplished under this procedure has frequently expressed the conventionalized thinking of the banker groups, who dominated the reorganization, in which there has been neither a proper reflection of the conceptions of the judicial statesmanship essential to the adequate adjustment of issues of such importance and involving such great sums, nor a real appreciation of the fiduciary relationship between those dominating the settlement of these conflicting claims and the owners of such claims. The reorganization plans have been the result of a process of bargaining between interests of unequal bargaining power, rather than of a process primarily one of adjudication. Often, committees purporting to represent security holders have been neither disinterested nor independent, and not infrequently they have represented conflicting interests. The expensiveness of the procedure, due in part to the extravagant fees allowed to reorganization managers, trustees, and counsel, and in part to the old-fashioned technique, has been notorious. ${ }^{12}$ Such conditions have put in jeopardy the rights of hundreds of thousands of creditors and investors who ordinarily are scattered, uninformed, and disorganized, and who can readily be misled or coerced. $^{13}$

Frequently the reorganization has resulted in unsound capital structures detrimental to the investors and to the interest which the general public has in these quasi-public corporations. ${ }^{14}$ These

creditors, he would not interfere. See also Frank, supra note 6 , at $7 x x, 712$; MouLTON, op. cit. supra note 6, at 353 .

12 Cf. United States v. Chicago, M., St. P. \& Pac. R. R., 282 U. S. 3 II (I93I); see H. R. Rep. No. 1897, 72 d Cong., 2d Sess. (I933) 6; Lowentril, THE INvesTor PaYs 255; Moulton, op. cit. stupra note 6, at 349 .

13 See Eastman, C., dissenting, in Chicago, M. \& St. P. Reorganization, I3I I. C. C. 673,701 (9928). The acquiescence of uninformed creditors and stockholders is ordinarily no real indication of the fairness of a plan. LOWENTHAI, THE INVESTOR PAXs 292; Frank, supra note 6, at 54I ; Moudton, op. cit. supra note 6, at 355. See, generally, Berle and Means, The Modern Corporatton and Private PROPERTY (1932).

14 See generally Mourton, op. cit. supra note 6, at 321 et seq. The reorganizations have been criticised as not providing for a proper reduction of fixed charges. "In the Milwaukee case [I54 I. C. C. 586 (I929)] there was an increase of interest charges from 21.5 million dollars to 22.8 million, inclusive of interest on income bonds. In the case of the Denver and Rio Grande Western three successive reorganization plans were approved within the space of three years. [70 I. C. C. 102 (Ig2I); 82 I. C. C. 745 (I923); and 90 I. C. C. I4I (I924)]. The first effected no 
corporations are public service companies. They afford arteries essential for the flow of national commerce. The bad effect of unsound capital structures upon their quasi-public functions has many ramifications. It is reflected importantly in the poor credit of the companies and their consequent inability to finance themselves readily and cheaply, and in their operating inefficiency, when, because of heavy fixed charges due to large capital burdens, an undue part of their earnings is diverted from maintenance and improvements. For many years the over-capitalization of certain railroads has been the outstanding source of public criticism and suspicion of all railroads. The efficiency and prosperity of some of the best railroads is attributable in large measure to sound reorganizations. ${ }^{15}$ Others have never succeeded in surmounting the obstacles created by unsound reorganizations. Because of the importance of sound reorganizations both to the investors and to the public, because of the immense investments involved, and because of the vulnerability of the litigants, the necessity of providing effective administrative machinery and sound reorganization principles has been peculiarly apparent.

Section 77 was hurriedly enacted in the last days of the Hoover administration in the effort to remedy these defects. Although it was not then regarded as a mature piece of legislation, ${ }^{16}$ and in spite of its faults, it was comprehensive, constructive, and progressive. It insured a reflection of the public interest by introducing a supervisory direction early in the proceedings. The influ-

reduction of fixed charges, and the second did not bring them within the probable earning capacity of the road, as was admitted in connection with the third reorganization, less than a year later." Moulton, op. cit. supra note 6, at 333. Also, see H. R. Doc. No. 89, 74th Cong., Ist Sess. (1935) I00. Surveys of the recent railroad reorganizations indicate that they have generally been favorable to the equity holders at the expense of the bondholders. See Bonbright and Bergerman, Two Rival Theories of Priority Rights of Security Holders in a Corporate Reorganization (I928) 28 CoL. L. REv. I27; Buscheck, A Formula for the Judicial Reorganization of Public Service Corporations (1932) 32 id. 964-68; DewINg, Financiar POIICY OF CORPORATIONS (r934).

15 The Union Pacific, Santa Fe, and Norfolk and Western are examples.

16 This was indicated in the statement of Senator Hastings in the Senate during its consideration of the amendments. See 79 Cong. REc. 13766 (1935). See also the letter of the Legislative Committee of the Interstate Commerce Committee to the Senate Committee on Interstate Commerce, dated Jan. 3I, I933, p. 3I, in which it indicated the view that the time was too short to perfect the draft of $\S 77$ as originally passed. 
ence of the Commission was brought to bear by requiring its approval, after hearings, of any plan before it could be approved by the court. A major improvement permitted the confirmation of reorganization plans over the protest of dissenting interests, whether creditor or stockholder, thus minimizing the obstructive powers of minorities. The administration of reorganizations was improved by vesting control of the entire property of the carrier in a single federal court and by giving the Commission and the court supervision of fees and expenses. ${ }^{17}$ A comprehensive system of reorganization under the bankruptcy power was provided.

The recent amendments are designed to make the Act more effective in the light of the experience with its use. The railroads, under the coincidence of the depression and the sharp effectiveness of the new competition of motor and other carriers, are now in the worst crisis of their history. They have been unable to secure the needed economies obtainable through such coördinative measures as saved the British railroads from government ownership, because of the labor limitations in the Emergency Railroad Transportation Act of $1933^{18}$ and a stubbornly conventional insistence by the public and by many of the managements upon the fullest measure of competitive action. Even with the aid afforded by the Reconstruction Finance Corporation, a very substantial part of the mileage of the country is now in bankruptcy or under reorganization in the equity courts. ${ }^{19}$ Consequently, an efficient reorganization machinery is now necessary.

When a new system of procedure is established, changing the established processes as radically as Section 77 did, it necessarily passes through an early period when it is untried and has not been accepted by the bar, and when there is uncertainty due to the fact that the precedents, yet to be established in its early interpretation and administration, are as important as the terms of the statute itself. The recent amendments have been made when that period was only well started. At this stage the possible alternatives open were: (I) to amend the Act, (2) to repeal it, (3) to repeal it and substitute a codification of equity procedure, and

17 Subdivisions (d), (e), and (g), respectively, of $\S 77$.

1848 STAT. 213, 49 U. S. C. § 257 (I935).

19 On March I, r936, a total of 74,922 miles of road owned was involved in reorganization in equity or bankruptcy. 
(4) to amend the Act and concurrently to provide a dual mechanism through a codification of equity procedure.

The considerations which inclined Congress toward amendments, rather than the other alternatives, were clear. There was no demand for a restoration of the status quo through repeal of the Act. While the bar naturally had little enthusiasm for a statute substituting an untried procedure for the established routines, the general dissatisfaction with equity procedure and the considerable measure of success of Section $77 \mathrm{~B}$ indicated the desirability of improvement of the Act. ${ }^{20}$ There was no reason for the establishment of a dual mechanism. The purpose of Section 77 was to provide an improved, workable, and comprehensive machinery. Why, then, should Congress amend the Act and, in addition, provide for a codification of equity? The House committee considered and rejected a bill intended to repeal the Act and to substitute a codification of equity procedure. ${ }^{21}$ This bill was rested on the power to regulate interstate commerce, and the bankruptcy power was to be abandoned. ${ }^{22}$ The House committee was apparently unwilling, in light of the Supreme Court's recent decision in Continental Illinois National Bank \& Trust Co. v. Chicago, Rock Island \& Pacific $R y{ }^{23}$ sustaining the constitutionality of Section 77 and strongly declaring the plenary nature of the bankruptcy power, to commit the legislation to the narrower and untried basis provided by the commerce power. ${ }^{24}$

20 Section 77 is one of three similar statutes drafted with the same basic conceptions. Section $77 \mathrm{~B}$ applies to industrial companies. 48 STAT. 9I2 (I934), II U. S. C. $\$ 205$ (I935). Section 80 applies to municipal corporations. 48 STAT. 798 (I934), II U. S. C. § 303 (I935). The decision not to repeal $\$ 77$ was influenced by the existence of these companion acts.

21 The bill was introduced in the Senate. S. 2906, 74th Cong., Ist Sess. (I935). No bill was introduced in the House, although it was presented for consideration to the committee. See Hearings before Committee on Judiciary on H. R. 6249, 74th Cong., Ist Sess. (I935) I64 et seq.

22 This was on the ground, among others, that reorganization in bankruptcy would be obscured or obstructed by precedents in bankruptcy, the technique of which was said to be geared to the winding up of affairs of small tradesmen. See Wehle, Railroad Reorganization under Section 77 of the Bankruptcy Act: Nere Legislation Suggested (I934) 44 Y XLE L. J. I97, 23x.

23294 U. S. 648 (I935).

24 Such a course would necessarily have committed the reorganizations to a period of great uncertainty arising from such debatable questions as whether the Congressional power to regulate interstate commerce extends so far as $(x)$ to permit it to confer exclusive jurisdiction for railroad reorganization to the federal courts and 
The opinion that the slow progress in the reorganization cases under Section 77 indicates that it is unworkable and cannot be made effective and that progress is to be found in the efficiency of the old equity process, seems to find refutation in the fact that progress in the forty-eight cases where the reorganizations are in equity is no more rapid than in the forty-four cases pending in bankruptcy. The delay has been due to conditions confronting the railroads which have resulted in such instability and uncertainty ${ }^{25}$ that neither the stockholders nor the creditors can be reasonably sure that reorganizations, whether in bankruptcy or equity, will not be unfavorable to their interests. A reorganization may restore credit and value where there is a substantial margin of profit or a fairly definite assurance of a rising income. This was the condition existing at the time of the very successful reorganizations accomplished after the 1893 depression. But no such margin of profit now exists, or is in early prospect, for the poorer railroads. ${ }^{26}$ Where there is a narrow margin of profit or

to oust state courts of the power to foreclose mortgages on property within their jurisdiction; and (2) to authorize a plan of reorganization assented to by designated majorities, but objected to by minorities, to become binding upon such dissenters. See Hearings before Committee on Judiciary on H. R. 6249, 74th Cong., Ist Sess. (1935) 3 I5 et seq.

25 Many elements now contribute to the instability of railroad revenues. To what extent has the competition of the truck virtually destroyed the railroad's property through the creation of functional depreciation? How far will that destruction be prevented by the recent legislation providing regulation of that competition? How far will the railroads be permitted, or willing, to effect a stabilization of the industry by such coördinative processes as were so successfully used in England? To what extent will the railroad revenues be impaired by laws recently passed and whose constitutionality is yet untested, such as the Guffey Coal Act, the Social Security Act, and the Railroad Pension Act; by such pending legislation as the Wheeler-Crosser bill (designed to prevent any laborsaving economies at any expense to labor), the full crew bill, and the train length bill; and by the results of investigations pending before the Interstate Commerce Commission involving the requirement of the installation of the automatic stoker and the power reverse gear? How rapid or steady is to be the country's recovery from the depression? Such factors make difficult the formation of the judgment as to the earning capacity of the carriers which is essential in testing the soundness of a reorganization plan, and retard reorganizations whether in equity or in bankruptcy. They preclude the conclusion that the delay in the reorganizations in bankruptcy has been due to any inherency in the bankruptcy practice incapable of improvement by amendment.

28 "The facts as to the radical differences between these two periods are obvious and simple. In 1894 the roads had, roughly, gross revenues of $\$ I, 000,000,000$, of which they saved $\$ 300,000,000$ for net, whereas in this depression, with a gross of $\$ 3, \infty \infty, 000,000$, the net was approximately the same as in I894. In other words, in 
no profit at all in the operations, credit and value will not be substantially restored, and many creditor and equity interests may be injured, by a premature reorganization. Industrial property can be abandoned when it does not pay operating expenses or produce an adequate margin of return above such expenses; or it can be sold to a different operator or for another kind of operation. But a railroad ordinarily cannot be abandoned, nor is there a similar opportunity for its sale. This lack of freedom of action is a condition which cannot be overlooked in the provision of administrative process or in the consideration of its efficiency.

The amendments which were made were, speaking roughly, of two general kinds: (a) those regarded as essential to make the Act more workable, particularly through providing a more effective technique in the treatment of non-assenting interests; and (b) those perhaps not essential to its workability, but designed to improve the Act in ways suggested by the experience in its administration (including many improvements which had been made in Section $77 \mathrm{~B}$ when it was enacted in I934). This article will be confined to a discussion of the amendments in the first group.

\section{Amendment Pertaining to the Requirement of Prompt Reorganizations}

The Act has been interpreted by the Supreme Court in the Rock Island case $^{27}$ as requiring prompt reorganizations. If not promptly accomplished, even if the conditions were such that delay might be in the good interest of all concerned, it was apparently the duty of the court to dismiss the case, in which event a reorganization in equity would ensue. But the progress in equity in these unstable

relation to gross the net today is one-third of what it was in the 'go's. You will also note that the $\$ 300,000,000$ of net in the ' 90 's compared with $\$ 37,000,000$ in taxes, which today amount to $\$ 275, \infty 00,000$. You will note, also, that this $\$ 300,000,000$ net compared with $\$ 446,000,000$ in payments to labor, which today amount to $\$ 1,500$,$\infty 00,000$. . . A A reduction of all these factors to their simplest form may be made by stating that the net in the '9o's was 28 per cent of the gross earnings, which was a safe margin. The net today is ro per cent of the gross earnings, which is an unsafe margin. With a sufficient margin, credit can be restored by a reduction of [fixed] charges; with an insufficient margin, no reduction of [fixed] charges can restore credit." Dick, Scaling Down Interest (r934) 97 RaIlWAY AGE 540, 54I.

27 Continental Illinois Nat. Bank \& Trust Co. v. Chicago, R. I. \& Pac. Ry., 294 U. S. 648 (I935). 
times is not being found more rapid. The dismissal of the proceedings in bankruptcy would, therefore, subject the reorganizations to the inefficiencies and abuses from which it was the purpose of Section 77 to rescue them, without accelerating their progress. The federal judges were restive under this admonition of the Supreme Court. ${ }^{28}$ It was clear that, under certain provisions of the Act (subsequently changed by an amendment about to be discussed), obstructive minorities could indefinitely delay the completion of a reorganization. It was consequently desirable to eliminate by amendment the necessity of action where haste is detrimental, and to make the Act more workable when conditions are favorable for action, particularly by enabling a more effective handling of the claims of the classes of stockholders and creditors.

In order to temper the effect of the decision in the Rock Island case, an amendment was made providing,

"If in the light of all the existing circumstances there is undue delay in a reasonably expeditious reorganization of the debtor, the judge, in his discretion, shall, on motion of any party in interest or on his own motion, after hearing and after consideration of the recommendation of the Commission, dismiss the proceedings." ${ }^{29}$

The effect of this amendment is not to provide a moratorium ${ }^{30}$ but to enjoin undue delay, thereby adopting in substance the rule

28 "The present law [ $\$ 77$ prior to amendment] contemplates hasty reorganizations. . . . The Federal judges . . . in a number of cases have issued orders indicating that unless the reorganizations are promptly accomplished, the cases will be thrown back into equity. This puts an unfortunate emphasis upon speed rather than soundness when the act is unworkable." Senator Wheeler, in 79 CoNG. REc. 13764 (I935). Also, see H. R. Rep. No. I283, 74th Cong., Ist Sess. (Committee on Judiciary, I935) 3 ; testimony of Mr. Eastman, in Hearings before Committee on Judiciary on $H . R$. 6249, 74th Cong., Ist Sess. (I935) 281; id. at 312 et seq.

29 Subdivision (g). This was substituted for subdivision (c) (7) of the original Act which provided for the dismissal of the proceedings if the plan were not proposed, accepted or approved in a reasonable time.

${ }^{30}$ In the absence of definite moratorium provisions based upon emergency conditions, bankruptcy legislation authorizing undue prolongation of the time of reorganization would undoubtedly be violative of creditor rights under the due process clause. Although the proceedings were in equity, the remarks of the Supreme Court in $R e$ Metropolitan Ry. Receivership, 208 U. S. 90 (I908), are significant. The court said: "We have no doubt, if unnecessary delays should take place, the court would listen to an application by any creditor ... for orders requiring the closing of the trust as soon as might be reasonably proper. . . ." 208 U. S. at II2. See also Feller, Moratory Legislation, A Comparative Study (I933) 46 HARv. L. Rev. I06I. 
prevailing in equity reorganizations. ${ }^{31}$ The Act, as amended, it is believed, is properly conceived of as a conservation measure ${ }^{32}$ permitting the carrier to remain under judicial control until reorganization becomes possible. Whether the proceedings are in equity or in bankruptcy, reorganization is not, as a practical matter, possible until a major portion of the creditors are willing to proceed. The constitutional validity of bankruptcy provisions as applied to railroads having such an objective is apparently not open to doubt. Such protection is essential to preserve the property. It has always been clear that in railroad reorganizations the equity courts will not, once their jurisdiction has been invoked, allow the property to be broken up and sold piecemeal. ${ }^{33}$ Failure to afford this protection would result in the disintegration of transportation facilities of vital interest to the public. ${ }^{34}$ The courts have recognized the difference between private and quasi-public businesses. While the Supreme Court has cast serious doubt upon the validity of such use of the equity receivership where an ordinary private corporation is concerned, ${ }^{35}$ it has sanctioned its use in railroad cases. ${ }^{36}$ The reason for this distinction lies in the public character of the property. ${ }^{37}$ The issuance of receivers'

31 Re Metropolitan Ry. Receivership, 208 U. S. 90 (Ig08).

32 The mere existence of a statute of this type has been said to imply a purpose of conservation. See GrenN, LrQuidation (I935) § 297.

33 "The necessity for these [railroads] receiverships for sheer purposes of conservation, - in other words, for purposes of reorganization, the receivership being regarded as 'the first step in the reorganization', was frankly recognized." GLENN, Liquidation § 172 . See Note (I930) 43 Harv. L. Rev. I298, x3or.

34 This would result through attachments or foreclosures of parts of the property.

35 "Ordinarily a creditor who seeks the appointment of receivers must reduce his claim to judgment and exhaust his remedy at law. . . . True indeed it is that receivers have at times been appointed even by federal courts at the suit of simple contract creditors if the defendant was willing to waive the irregularity and to consent to the decree. This is done not infrequently where the defendant is a public service corporation and the unbroken performance of its services is in furtherance of the public good. Re Metropolitan Railway Receivership, 208 U. S. 90, I09, III. It has been done at times, though the public good was not involved, where legitimate private interests might otherwise have suffered harm. ... We have given warning more than once, however, that the remedy in such circumstances is not to be granted loosely, but is to be watched with jealous eyes." Shapiro v. Wilgus, 287 U. S. 348 , $355-56$ ( $x_{932}$ ). See also Harkin v. Brundage, 276 U. S. 36 ( $x_{928)}$.

${ }^{36}$ See Re Metropolitan Ry. Receivership, 208 U. S. 9o (I908); GrenN, LIQUDATTON \& I72.

37 "All the cases in which this Court appears to have exercised this power in 
certificates to pay operating expenses, which certificates take precedence over mortgage bonds executed prior thereto, ${ }^{38}$ is an expression of the same reasoning. Where a reorganization is presently impracticable because of the unwillingness of the creditors to proceed with a reorganization, it seems clear that authority may be properly granted to the court to retain jurisdiction over the property until the situation becomes favorable to reorganization. The scope of the bankruptcy power, discussed hereinafter, is sufficiently broad that there would seem to be no doubt that Congress can confer upon the bankruptcy court the same degree of control of property undergoing reorganization as heretofore exercised in the equity courts.

\section{Amendments Pertatning to Classification of Clatms AND to REFERENDUM ON REORgantzation PLANS}

Greater efficiency in the classification of the claims of creditors and stockholders was regarded as necessary because of the complexity of the railroad reorganization cases. In the pending Missouri Pacific case there are fifty thousand bondholders, ten thousand stockholders, and between two and three thousand general unsecured creditors. These have been segregated into seventy-two separate classes. ${ }^{39}$ In some instances the single claim of one creditor has been put into a separate class, as, for example, the six million dollar loan of J. P. Morgan and Company to the

aid of reorganization upon the ground of insolvency dealt with railroads or other public utilities where continued operation of the property and preservation of its unity seemed to be required in the public interest." First Nat. Bank v. Flershem, 290 U. S. 504, 515, n.7 (1934).

38 Such certificates may take priority over rents and profits arising during the receivership and over the proceeds from the sale of previously mortgaged property. Union Trust Co. v. Illinois Midland Ry., II 7 U. S. 434 (x886). Similarly, it has been held that where unsecured obligations, incurred not more than six months prior to insolvency, were necessary to the continued operation of the business, the holders thereof were entitled to be preferred over bondholders under a previously existing mortgage. The basis of these decisions is the necessity of continued operation of the railroad properties. Miltenberger v. Logansport Ry., I06 U. S. 286 (I882); Gregg v. Metropolitan Trust Co., I97 U. S. I83 (I905); see Wham, Preference in Railroad Receiverships (1928) 23 Irx. L. Rev. I4r.

39 See Hearings before Committee on Judiciary on $H . R$. 6249, 74th Cong., Ist Sess. (1935) 26; SEN. REP. No. 1336, 74th Cong., Ist Sess. (Committee on Interstate Commerce, I935) 2. 
Missouri Pacific. ${ }^{40}$ This multifarious creation of classes elevated minorities into a position of undeserved obstructive power. In part, this power lay in the provisions of the Act, about to be discussed, pertaining to the approval of plans by the respective classes, and in part, in the difficulty in the determination of the value of the property, either for the purpose of determining insolvency (it being unnecessary to secure the approval of the equity holders if insolvency were thus established), or for fixing the value of interests of dissenters for which a plan made provision for cash payments. These classification and valuation provisions would naturally stimulate the obstruction of plans by the minorities in these many classes, since the possibility of their securing full payment or preferred treatment as a necessary concession to avoid elaborate valuation proceedings would tend to encourage their non-agreement. The smallness of such groups, or putting a single claim in a class by itself, facilitates quick and aggressive action. The difficulty of raising cash to pay the claims of such dissenters constitutes an invitation for inordinate demands as the price of acquiescence. Consequently, the practical course open to those promoting reorganizations would be to acquiesce in concessions, justifiable only because of the tactical strength of such groups, and often made at the expense of creditors with stronger substantive rights but in weaker strategic positions. Such considerations indicated the desirability of improvements permitting a more efficient treatment of minority interests. To this end amendments were made intended to improve the classification of the creditors and the manner of their voting, to simplify the valuation, and to make more workable the provisions permitting the confirmation of plans not approved by two thirds of the holders in any class of creditors or stockholders.

In order to prevent undue multiplicity of classes, an amendment was made providing that there shall be no classification into separate classes in the absence of " substantial differences in priorities, claims, or interests." 41 This provision is as specific as the

40 This claim was ordered to be classified with the claims of Reconstruction Finance Corporation and Railway Credit Corporation after the passage of the amended Act. N. Y. Times, Dec. 20, I935, p. 39, col. 7.

41 Act of Aug. 27, I935, c. 774, 49 Stat. 916, II U. S. C. A. § 205 (c) (7) (Supp. I935). 
subject matter permits and, interpreted in the light of the Congressional history, should be effective for its purpose.

The Act was amended to facilitate the confirmation of plans by making unnecessary the securing of the vote of holders who refuse or neglect to vote or who cannot be located, by providing that the judge shall confirm the plan if it has been accepted by the designated majority of the total in each class who vote, rather than of the total in each class. ${ }^{42}$ The effect of the original provisions of the Section was to count as against the plan all who did not vote. This was unreasonably obstructive. The stocks and bonds of these corporations are owned by persons scattered over the world. It is apparent that in many cases the vote of a substantial percentage of owners, uninterested and unknown, cannot be obtained. There is no sound basis for a conclusive presumption that those who are too uninterested to vote, or who cannot be located, would reject the plan. The Supreme Court has sustained the constitutionality of a provision, in a state statute authorizing reorganizations, to the effect that non-voters are deemed to have assented, following the analogy of the statutes of limitations which rest on the reasoning that those who neglect to act may be assumed to have abandoned their cause of action. ${ }^{43}$ The amendment seems sound for the same reason.

Under the amended Act the submission of the plan to creditors and stockholders is made after the plan has the prestige arising from its approval both by the Commission and the court. ${ }^{44}$ Prior to the amendment the submission was made after the approval of

42 Subdivision (e).

43 Gilfillan v. Union Canal Co., rog U. S. 40r (I883). The provisions of the Act requiring precautions for full notice have been strengthened. The judge must require the debtor or the trustees to file with the court a list of all known bondholders, creditors and stockholders, with their last known postoffice address or place of business. Subdivision (c) (4). A new provision has been added under which it shall be the duty of anyone having information as to such names and addresses to divulge such information to the trustee or trustees upon written request therefor. Upon petition by any party of interest, the judge may order the production of such information by anyone refusing to divulge it. Subdivision (c) (5). The purpose of this provision is to deprive anyone having such information of any undue advantage arising from its possession. In the past, certain investment institutions are said to have had an undue advantage in reorganizations through private information as to the names and addresses of the security holders.

44 Subdivision (d). 
the Commission but before the confirmation of the court. The amended Act also provides that the submission itself is to be made by the Commission. This is in contrast with the practice contemplated under the original Act whereby reorganization managers or committees, who were instrumental in putting through a plan, obtained from creditor and stockholder interests, ordinarily without a disclosure of the particular plan to be proposed, authority to vote their claims. The difficulty of securing the approval of two thirds of all outstanding holders tended to stimulate high pressure methods. Under the arrangement now provided, the Commission, as a disinterested agency, conducts a referendum of the claimants, who are free from any domination or control by the committees. This arrangement, in conjunction with the elimination of the necessity of securing two thirds of the entire number of claimants in a particular class, and the provisions under which any interested party can propose a plan, together with those under which the Commission can approve a plan different from any proposed to it, ${ }^{45}$ should facilitate the consummation of plans.

\section{Amendments Designed to Factlitate ConfrRmation of Plans not Accepted by Two Thirds of CREDITORS AND STOCKHOLDERS}

Section 77, before amendment, permitted reorganizations in several ways. A plan, when approved by the Commission and confirmed by the court, could become effective upon acceptance by two thirds in amount of each class of creditors and stockholders. If that consent were withheld by any class of creditors, a plan could nevertheless become effective if it provided for a sale of the property subject to the lien of such dissenting class, or for a sale of the property free from such liens at not less than a fair upset price, or for protection of the creditors by an appraisal of their interest and the payment in cash either of the value of their claims or of the securities allotted to them under the plan. Similarly, where consent of two thirds of any class of stockholders was not obtained, a plan might become effective where it provided for a sale of the property at not less than a fair upset price, or where it protected such interest by providing for an appraisal and a pay- 
ment in cash either of the value of the interest, or, at the objecting stockholders' election, of the value of the securities, if any, allotted to such stock under the plan. A plan could become effective without the consent of the stockholders if the company were found to be insolvent (as the result of a determination of the value of the assets by the court),${ }^{4 B}$ or if the plan did not adversely affect such stockholders, or if they were bound by the company's acceptance of the plan. ${ }^{47}$

Although these alternatives were authorized, the only practicable one was that which involved a judicial sale of the property at an upset price. The other alternatives were ineffective because of the difficulty of obtaining the necessary consent of the junior creditors and stockholders. Their great number and their being widely scattered and difficult to locate were in themselves serious obstacles to obtaining such approvals. The difficulties inherent in making a valuation of such great properties and the uncertainty as to what its result would be (unless the process were simplified and made definite by suitable amendments) made impracticable either the elimination of the stockholders' approval by the proof of insolvency, or the resort to cash payment to dissenters of the appraised value of their interests. In the pending reorganization of the St. Louis and San Francisco system, the Commission, knowing, after twenty-two years' experience with the LaFollette Valuation Act, the laborious nature of such valuation determinations, recognized the impracticability of an attempt by the court to determine insolvency on a valuation basis and postponed such action until amendment of the statute. ${ }^{48}$

On the other hand, the restriction of the processes to those involving a sale at an upset price was a serious limitation. The use of the device of the sale at an upset price in a railroad bankruptcy statute is an adaptation of legal machinery to a task quite different from that for which it was designed or for which it is suitable. ${ }^{40}$ There ordinarily can be no such thing as a public sale of such

46 Subdivisions (e), (h).

47 Subdivision (e).

48 See Sen. Rep. No. 1336, 74th Cong., Ist Sess. (Committee on Interstate Commerce, 1935) 3; Hearings before Committee on Judiciary on H. R. 6249, 74th Cong., Ist Sess. (1935) 26.

49 It has been pointed out that the reorganization technique used in equity is outmoded machinery adapted to the localized factory or butcher shop. See Swaine, supra note 6, at 3 I7. 
properties. Were the property put up at an actual auction, the court would fix an upset price to prevent a chilling of the bidding. But ordinarily the only possible purchasers at a railroad reorganization sale are the holders of the majority of the securities of the old company, and there can be no competitive bidding. ${ }^{50}$ The practice has been, therefore, for the court to set an upset price, below which it would not confirm a sale and which was sufficiently low to drive the interested parties into the reorganization. ${ }^{51}$ It has been necessary that the cash allocable to such dissenters be appreciably less than the value of the securities offered under the plan. ${ }^{52}$ Otherwise they would not take the securities, and the

50 ". . . it rarely happens in the United States that foreclosures of railway mortgages are anything else than the machinery by which arrangements between the creditors and other parties in interest are carried into effect, and a reorganization . . brought about." Canada Southern Ry. v. Gebhard, rog U. S. 527, 539 (I883). "A foreclosure sale is not a foreclosure sale at all but merely a left-handed device to effect a reorganization." Spring, supra note 6, at 5or. In Kansas City Terminal Ry. v. Union Trust Co., 27 I U. S. 445, 455 (I926), the Supreme Court observed: "Practically, it is impossible to sell the property of a great railroad for cash. . . . the large amount of cash required by the upset price renders the [railroad] Reorganization Committee, which ordinarily controls a large majority of the outstanding securities, practically the only bidder." First Nat. Bank v. Flershem, 290 U. S. 504, 526 (I934). See also Frank, supra note 6, at 54I, 5\%o. An outside bidder almost never appears. See Byrne, Foreclosure of Railroad Mortgages in Some Legar Phases of Corporate Financing, Reorganization and Regulation (x9I7) 77, r4I; Cravath, Reorganizations of Corporations, id. at I53; Rosenberg, A New Scheme of Reorganization in Corporate REorganization aNd tHe Federal CourTs (I924) I, 5 ; Weiner, Conflicting Functions of the Upset Price in a Corporate Reorganization (I927) 27 CoL. L. REv. I32, I37, n.28.

51 After it has been fixed, minority interests have dwindled to insignificance. Bonbright and Bergerman, supra note I4, at I28; Weiner, supra note 50, at I32.

52 ". . . the courts have been obliged to fix an upset price that does not represent the full value of a bondholder's interest in the property as a going concern. And it follows that a dissenting bondholder may be treated with gross unfairness in the reorganization agreement and yet may be forced to accept these unfair terms rather than to take the still more niggardly cash settlement that is offered to him if he remains a dissenter." Bonbright and Bergerman, supra note I4, at I27-28. See also Moutron, op. cit. supra note 6, at 324. "Deponent has examined the decrees of foreclosure and sale in many other reorganizations and the quotations of the market prices of the bonds affected by such reorganizations and has found it the rule that the minimum bid or upset price fixed by such final decrees, or the bids actually confirmed by the courts, have uniformly been such as do result in a distribution share for the bonds secured by the foreclosure mortgages substantially less than the market value of those bonds during the period preceding the promulgation of the reorganization plan. The relation of the distributive share to the market value of the bonds has ranged from as low as ro\% of the market value to as high as $80 \%$ of the market value." Deposition of Mr. Sunderland in Weiner, supra note 50, 
reorganization could not be effected. In practical effect, therefore, the only alternative afforded the dissenters has been to accept the securities of the reorganized company. Under these circumstances, since no rationale supports the use of the upset price device, no logic supports the adoption of any particular theory for fixing what it should be. The pertinent decisions reflect this artificiality and are chaotic. Some courts have fixed the price at an amount equaling the costs of the litigation and the outstanding receivers' certificates, a basis affording no protection to dissenting interests; others have used the capitalization of the present earnings, when they obviously are not indicative of true value because temporarily depressed; others have used the junk value when the property cannot be abandoned and abandonment is not contemplated; many cases are wisely silent as to the basis of determination. ${ }^{53}$ It is, of course, clear that in determining the rights of the creditors and stockholders, it is not to be assumed that the property of the magnitude of a large railroad has no value because it cannot be sold. The very great amount of property owned by the typical railroad prevents its sale as a unit even if the railroad is highly prosperous, and yet it may be of very great value.

It is thus apparent that the upset price device affords no adequate basis for a careful adjudication of the property rights which depend upon the value of the assets. It does not purport to afford any actual determination of that value. Nor is the sale what it purports to be. The sale and the upset price are merely elements of an artificial procedural technique used to drive creditor and equity interests into the reorganization plan.

The circumstance, already alluded to, that Section 77 in its original form was so designed as to be peculiarly susceptible to abuse by obstructive minorities, coupled with the defects in the upset price device just described, made it desirable that the previously unworkable valuation provisions of Section 77 be so improved that creditors or stockholders could be excluded, either

at $\mathrm{I43}_{4}$. In the Milwaukee reorganization, under the upset price there fixed, the bonds had a cash realizable value of $\$ 4 \mathrm{x}$. The current market appraisal of the value of the securities offered under the reorganization was $\$ 55$. See Weiner, supra note 5o, at $\mathrm{x}^{2}, \mathrm{I} 44$.

53 See Bonbright and Bergerman, supra note 14, at I27; Weiner, supra note 50, at I32, 143 . 
totally or partially, from participation in a reorganization plan on the basis of a valuation of the assets determined according to sound and definite principles and under a simplified evidentiary practice. Without eliminating the possibility of the use of the sale at an upset price, it was desirable to make practically effective the alternative method of reorganization under which a plan could be consummated without the necessity of a sale of the property, ${ }^{54}$ and to include provisions making it possible, in appropriate circumstances, to compel minority holders to accept securities in the recognized company despite their refusal to assent to the provisions of the plan.

\section{Valuation Provisions}

Amendments simplifying and clarifying the determination of the valuation were required, because the provisions of the original Act enabling an elimination of the consent of claimants demonstrated to have no interest by a valuation, or for the value of whose interest a cash payment was provided, were regarded as unworkable because of the great task of valuing property of such magnitude and because of uncertainty as to the results, due to doubt as to the legal principles governing such a valuation. ${ }^{55}$ The assignment of the determination to the courts, as provided in the original Act, was inappropriate. The courts are ordinarily inexperienced

54 Coriell v. White, 54 F.(2d) 255 (C. C. A. 2 d, x93 I), a case which arose in an equity proceeding and not under a bankruptcy statute, held that while the creditor is entitled to the cash value of his claim and cannot be compelled against his will to take new securities in a reorganization, the right to a sale is not a substantial right but a mere procedural remedy for which in a particular case there may be the substitution of a substantial equivalent such as appraisal. The point was not passed upon by the Supreme Court on appeal. National Surety Co. v. Coriell, 289 U. S. 426 (x933). Ample precedent for such a view is found in the decisions refusing to set aside sales by corporations of substantially all their assets for stock of another corporation to be distributed to the selling corporation's stockholders, when consented to by substantially all the stockholders, even though there be no statutory authority for a sale for a consideration other than cash. Geddes v. Anaconda Copper Mining Co., 254 U. S. 590 (I92I) ; Jackson Co. v. Gardiner Investment Co., 200 Fed. II3 (C. C. A. Ist, I9I2); see Maxler v. Freeport Bank, 275 Pa. 5IO, 5I3, II9 Atl. 592, 593 (I922). But cf. Mason v. Pewabic Mining Co., I33 U. S. 50 (I89o); see Swaine, supra note 6 , at $31 \%, 325$.

55 See Bonbright and Pickett, Valuation to Determine Solvency under the Bankruptcy Act (1929) 29 Cor. I. Rev. 582; Wehle, supra note 22, at 209; testimony of Mr. Eastman, in Hearings before Committee on Judiciary on $B . R .6249,74^{\text {th }}$ Cong., Ist Sess. (1935) 283 et seq. 
with this technical problem, while the Commission has had extended experience since I9I3 in its administration of the LaFollette Valuation Act. This experience has indicated great difficulty in making such determinations, if the kind of value to be determined in a reorganization case is the same as a value for rate-making purposes under the principles of Smyth v. Ames. ${ }^{58}$ The ratemaking valuation cases tried by the Commission and by the state commissions are almost without parallel in our litigation in point of magnitude and complexity. ${ }^{57}$ The doctrine of Smyth v. Ames, that the determination of value for rate-making purposes is a question of fact to be determined in the light of all the relevant facts, produces numerous highly controversial issues involving great detail concerning such things as the present cost of reproduction, the original cost to date, the investment, the accrued depreciation, the value of the land, going value, and working capital. The obstructive possibilities open to the equity and creditor interests, through the probability of prolonged hearings and litigation involving these complicated questions, were evident from the Commission's valuation cases. That the equity interests were well aware of the strategic value to them of the original provisions of Section 77 was evidenced by the insistence with which they fought any simplification of the process. They asserted that value in a reorganization case is the same as in a rate case. ${ }^{58}$

The new statute contains provisions similar in substance to those of the original Act with reference to excluding stockholders from participation or paying the value of their interest in cash. Submission of a plan to any class of stockholders is unnecessary if the Commission finds, and the judge affirms the finding, that the corporation is insolvent, that their equity has no value, or that the plan provides for the payment in cash to such class of an amount not less than the value of its equity, if any. It provides that submission to the creditors shall be unnecessary if similar findings are made with reference to them. ${ }^{50}$ The amended Act

\footnotetext{
56 I69 U. S. 466 (I898).

57 For a discussion of the delay, complexity, and cost of hearings involving rate-making valuations, see Brandeis, J., dissenting, in St. Joseph Stockyards Co. v. United States, U. S. Sup. Ct., April 27, 1936.

58 See Hearings before Committee on Judiciary on H. R. 6249, 74th Cong., Ist Sess. (1935) r52, 215 et seq., 29 I et seq.

69 Subdivision (e). The similar provisions applicable to creditors are that
} 
carries the following provisions with reference to the determination of value:

"If it shall be necessary to determine the value of any property for any purpose under this section, the Commission shall determine such value and certify the same to the court in its report on the plan. The value of any property used in railroad operation shall be determined on a basis which will give due consideration to the earning power of the property, past, present, and prospective, and all other relevant facts. In determining such value only such effect shall be given to the present cost of reproduction new and less depreciation and original cost of the property, and the actual investment therein, as may be required under the law of the land, in light of its earning power and all other relevant facts." 60

The purpose of these provisions is to lodge the determination of the value in the Commission in the first instance, and to incline the determination away from the doctrine of Smyth $v$. Ames, ${ }^{61}$ under which the value is fixed on the basis of a consideration of the original and reproduction cost of the property and the investment therein. The actual value of the property cannot be determined, nor is it ordinarily evidenced by the investment in the property or its present cost of construction. The railroads are competitive properties. The value of their operative property, for purposes of reorganization, must necessarily be what, for better terms, we may call the actual value or the economic worth of the property, as determined primarily by its present and prospective earning capacity. ${ }^{62}$ The actual value of the property depends upon the demand for its service and its ability to meet the demand economically. The provisions of the amended statute, therefore, make clear that emphasis shall be put on a consideration of earning power, past, present, and prospective. Were the insolvency of railroad properties to be determined on the basis of the value for rate-making purposes heretofore made by the Commission, al-

submission to any class shall be unnecessary if the Commission shall have found, and the judge shall have affirmed the finding, that the interests of such class have no value or that the plan provides for the payment in cash to such class of creditors of an amount not less than the value of their interests.

Bo Subdivision (e).

61 I69 U. S. 466 (I898).

62 Cf. Monongahela Navigation Co. v. United States, 148 U. S. 312 (1893); Cleveland, C., C. \& St. L. Ry. v. Backus, I54 U. S. 439 (I894). 
most no railroad in the country would be insolvent, for this socalled "value" was determined on the basis of the cost of the property and without any regard for its earning capacity, the Commission having held that a valuation made for the fixation of rates must be made independently of any consideration of earnings. ${ }^{63}$ This eliminated from consideration the element which in fact precipitates insolvency - the failure to obtain a return adequate to meet the claims of creditors.

It was furthermore important to prevent the obstruction of the hearings by the introduction, where improper, of testimony with reference to the original and reproduction cost of the property and the investment therein. In cases involving property of such magnitude, for reasons already explained, such evidence is necessarily of great bulk and detail and its introduction affords unlimited possibilities of delay. On the other hand, evidence of the earning power of the property is comparatively simple. The amendment does not, however, provide for the exclusion of testimony relative to the original or reproduction cost or the amount of the investment, nor does it prescribe its evidentiary effect, if admitted. The amendment, by its emphasis on earning power, ${ }^{64}$ permits exclusion of testimony as to the present cost of reproduction new and original cost unless the admission of such testimony in the particular case is required by the law of the land. The Supreme Court, since the passage of these amendments, has affirmed the

63 San Pedro, L. A. \& S. L. R. R., 75 I. C. C. 463 (1923) ; Kansas City S. Ry., 84 I. C. C. $\operatorname{Ir}_{3}$ (I924).

64 In using the language employed, Congress followed the precedent of the similar, and rather unusual, provisions in $\S$ I5a of the Interstate Commerce Act, that in determining the value of property for recapture purposes, the Commission "shall give due consideration to all the elements of value recognized by the law of the land for rate-making purposes, and shall give the property investment account of the carriers only that consideration which under such law it is entitled to in establishing value for rate-making purposes." 4I STat. 489 (r920), amended, 48 STAT. 220 (I930), 49 U.S.C. $\$ 15 a$ (I935). Such provisions are cautionary. They are not intended to prescribe a formula, but to put the Commission on guard. The effectiveness of such provisions is evidenced by the fact that for a failure to follow the requirement of a consideration of present reproduction cost among the "elements of value recognized by the law of the land," the Commission was reversed by the Supreme Court in St. Louis \& O'Fallon Ry. v. United States, 279 U. S. 46I (I929). A more direct prohibition of the receipt or consideration of evidence of cost and investment would involve danger of invading guarantees of due process, at least in some cases. 
Commission in making the distinction between the actual value and a "value for rate purposes" which is not value at all but a rate base, and in holding that the cost of reproduction is not ordinarily of any weight in determining the actual value. In a case involving the Commission's determination of the actual value of property, as distinguished from a rate base, the Court quoted with approval the Commission's dicta: "Clearly the only pertinent value is that for purposes of sale or exchange. Cost of reproduction is to be given little, if any, weight in determining such value, in the absence of evidence that a reasonably prudent man would purchase or undertake the construction of property at such a figure." ${ }^{65}$ Under these principles, a court would be justified in not receiving evidence of the investment in, or the original or reproduction cost of, the operating property unless its present or prospective earning capacity were adequate to justify the investment of such sums. ${ }^{68}$

\section{Provisions Permitimg Confirmation of Plans not Accepted by Two Thirds of the Creditors AND STOCKHOLDERS}

Section 77 , as originally enacted, employed the principle of the composition $^{67}$ in provisions authorizing confirmation of a plan

65 Atlanta, B. \& C. R. R. v. United States, 296 U. S. 33, 39 (1935), aff'g Re Atlantic Coast Line R. R. and Atlanta, B. \& C. R. R., 20I I. C. C. 645 (I934).

$\mathrm{Wm}$. O. Douglas has suggested that the valuation difficulty might be met at least in part by a rule of thumb that stockholders need not be offered participation if for a certain period of years prior to bankruptcy or reorganization, the railroad had not, on an average, earned its fixed charges. Protective Committees in Railroad Reorganizations (I934) 47 HARv. L. Rev. 565,589 , n.42. Railroad earnings are subject to such wide variations, due to local or temporary conditions, that it is unlikely that any such test period could be selected which would not be unreasonably arbitrary.

66 See United States v. Boston and New York Canal Co., 27x Fed. 877, 889 (C. C. A. Ist, I92I).

67 " As outlined by that section [ $\$ 77]$, a plan of reorganization, when confirmed, cannot be distinguished in principle from the composition with creditors authorized by the act of 1867 , as amended by the act of 1874. ." Continental Illinois Nat. Bank \& Trust Co. v. Chicago, R. I. \& Pac. R. R., 294 U. S. 648, 672 (I935).

The composition was authorized in the Bankruptcy Act of 1867 , as amended in r874, and was sustained In re Reiman, 20 Fed. Cas. No. II,673 (S. D. N. Y. I874). This case was cited with approval by the Supreme Court in Hanover Nat. Bank v. Moyses, I86 U. S. I8r, I86 (I902), and in Continental Illinois Nat. Bank \& Trust Co.v. Chicago, R. I. \& Pac. Ry., supra. 
which became binding on creditor and stockholder minorities when it had been accepted by two thirds in amount of each class whose interests would be affected by its provisions, and when it had been approved by the Commission and confirmed by the court. ${ }^{68}$ Under the amended Act a plan would become effective under similar circumstances. $^{69}$ But for reasons already indicated, the amended Act goes further and provides that a plan may, in certain circumstances, become binding notwithstanding it has not been accepted by the prescribed vote of the classes of creditors and stockholders. This provision was added in order to reduce the power of minority holders to force inequitable adjustments as the price of their acquiescence.

Under the amended Act, the plan, upon approval by the Commission, is at once certified to the court. ${ }^{70}$ The judge, after a hearing, is required to approve the plan if satisfied that, among other things, it is

"fair and equitable, affords due recognition to the rights of each class of creditors and stockholders, does not discriminate unfairly in favor of any class of creditors or stockholders, and will conform to the requirements of the law of the land regarding the participation of the various classes of creditors and stockholders. . . ." 71

The plan is then submitted to the stockholders (submission to any class being, however, unnecessary if the court shall have found that the corporation is insolvent, that the equity of the class has no value, or that the plan provides for the payment in cash of the value of the equity), and to the creditors (with exceptions simi$\operatorname{lar}^{72}$ to those stated within the foregoing parentheses). If two thirds in amount of the total of the allowed claims in each class of creditors, and two thirds of the stock in each class, who vote in the submission, vote favorably, the judge shall confirm the plan, and it shall bind the minorities in such classes. Then follow the provisions critical in this discussion: if the plan has not been so accepted, the judge may nevertheless confirm it if he shall find, after

68 Subdivisions ( $f$ ) and ( $g$ ) of $\$ 77$ before amendment require the plan to be equitable, not to discriminate unfairly in favor of any class of creditors or stockholders, to be financially advisable, and to be compatible with the public interest.

69 Subdivisions (e), (f).

70 Subdivision (d).

71 Subdivision (e).

72 See note 59 , supra. 
hearing, that it conforms to the provisions stated in the foregoing indented paragraph and that

"it makes adequate provision for fair and equitable treatment for the interests or claims of those rejecting it; that such rejection is not reasonably justified in the light of the respective rights and interests of those rejecting it and all the relevant facts. . . ." 73

Under Section 77 before amended, if creditors holding two thirds in amount of the claims of a class approved a plan, a dissenter in such class was bound if the judge found that the plan was fair and equitable and did not discriminate in favor of any class of creditors or stockholders. This obviously impairs the creditors' technical right to have the property subjected to their foreclosure. That they can be deprived of such rights was forecast by the Supreme Court in Canada Southern Ry. v. Gebhard, ${ }^{74}$ and sustained in Continental Illinois Bank \& Trust Co. v. Chicago, Rock Island \& Pacific $R y^{75}$

To what extent does the amendment differ from the original provisions? Before amendment the Act required that the plan be found to be fair and equitable and not to discriminate unfairly in favor of any class. Those provisions remain unchanged, and the requirement has been added that the plan shall afford due recognition to the rights of each class and shall conform to the requirements of the law of the land regarding their participation. Before the court may override the rejection of the plan, it must, after hearing, make the additional findings that the plan makes adequate provision for fair and equitable treatment of the interests or claims of those rejecting it, and that such rejection is not reasonably justified in the light of the respective rights and interests of the rejecters. Thus, where the dissenters have refused to accept a plan found to meet the requirements of substantive law determinative of their interest, the court is empowered to inquire into the reasonableness of their rejection and to overrule it if it shall find that the rejection is not reasonably justified.

These provisions are valid, it is believed, as a reasonable exer-

73 Subdivision (e).

74 Iog U. S. 527 (1883).

75294 U. S. 648 (I935). 
cise of the bankruptcy power. The breadth and progressiveness of this power is indicated in the opinion in the Rock Island case by the following statement of the Court:

"The fundamental and radically progressive nature of these extensions [of the bankruptcy power] become apparent upon their mere statement. . . . Taken altogether, they demonstrate in a very striking way the capacity of the bankruptcy clause to meet new conditions as they have been disclosed as a result of the tremendous growth of business and the development of human activities from 1800 to the present day." 78

The bankruptcy clause is limited by the due process clause. The conception of what is due process is not limited to the vision of any particular time but is adaptable to the changing needs of the time. The Supreme Court has said: ". . . while the meaning of constitutional guaranties never varies, the scope of their application must expand or contract to meet the new and different conditions which are constantly coming within the field of their operation. In a changing world, it is impossible that it should be otherwise." 77 It has often been held that the requirement of due process is that the legislation be directed to a proper legislative purpose, and be neither arbitrary, discriminatory, nor capricious. $^{78}$ This conception of due process would seem to permit

76294 U. S. at 67 .

77 Village of Euclid v. Ambler Realty Co., 272 U. S. 365,387 (1926). In Home Bldg. \& Loan Ass'n v. Blaisdell, the Court said: "If . . . it is intended to say that the great clauses of the Constitution must be confined to the interpretation which the framers, with the conditions and outlook of their time, would have placed upon them, the statement carries its own refutation. It was to guard against such a narrow conception that Chief Justice Marshall uttered the memorable warning 'We must never forget that it is a constitution we are expounding;' (McCulloch v. Maryland, 4 Wheat. $3 \times 6,407)-$ 'a constitution intended to endure for ages to come, and, consequently, to be adapted to the various crises of human affairs." " 290 U. S. 398, 442-43 (r934). Cf. The Propeller Genesee Chief, r2 How. 443 (U. S. 185I) ; South Carolina v. United States, x99 U. S. 437 (Ig05); Atchison, T. \& S. F. Ry. v. United States, 284 U. S. 248 (I932).

78 "And the guaranty of due process, as has often been held, demands only that the law shall not be unreasonable, arbitrary or capricious, and that the means selected shall have a real and substantial relation to the object sought to be attained." Nebbia v. New York, 29I U. S. 502, 525 (I934); Home Bldg. \& Loan Ass'n v. Blaisdell, 290 U. S. 398 (I934). ". . . the highest court and most high courts have refused to regard constitutions as codes, and of late years have more and more made due process of law whatever process seems due to the demands of the times, as under- 
elimination of the requirement of a favorable vote of the creditors under circumstances where the reason for the requirement does not exist. Such is the case where railroad reorganizations are concerned. The composition principle, whereby minority creditors can be bound by majority vote, was evolved when property holdings were relatively small, and the insolvent was usually an individual or a small business. Significance could be attached to the vote of a majority of such creditors concerning the fairness and desirability of a particular plan of financial rearrangement. The interested parties ordinarily knew the debtor and had a first hand understanding of his comparatively simple problems. On the other hand, the Missouri Pacific Railroad, to take a typical case, operates properties in a dozen states; its reorganization involves complex business problems and a highly complicated financial structure; its uninformed creditors, over fifty thousand in number, are scattered all over the world. Further, this statute involves public service corporations which furnish arteries of the national commerce, in the financial structure of which the public has an interest, because of its effect upon the capacity of these corporations to perform quasi-public functions. The significance of this distinction is well recognized. ${ }^{79}$ A vote of railroad creditors or stockholders, under all these circumstances, may be a factor ${ }^{80}$ to be considered with respect to the fairness and practicability of a reorganization plan, but it can hardly rise to the

stood by the judges of the time being." Hough, Due Process of Law-Today (IgIg) 32 HARv. L. REv. 2I8, 233. That the provisions under discussion are not violative of the creditors' rights under practical conceptions of due process is indicated by the support given them before the House committee by the associated life insurance companies holding railroad bonds in the amount of $\$ 2,000,000,000$ out of a total of $\$ 3,000,000,000$ held by all life insurance companies, and by the National Association of Mutual Savings Banks holding railroad bonds in the amount of over $\$ 1,600,000,000$. See Hearings before Conmittee on Judiciary of H. R. 6249, 74th Cong., Ist Sess. (I935) 74, 86, Ior.

79 First Nat. Bank v. Flershem, 290 U. S. 504 (I934); see Spaeth, The Reorganization Amendments to the Bankruptcy Act (1934) 8 TEMP. L. Q. 447; Payne, Fair and Equitable Plans of Corporate Reorganization (I933) 20 VA. L. REv. 37, 52; Note (1933) 42 YALE L. J. $387,398$.

80 It has been pointed out that the assumption that in reorganization matters the will of the majority is synonymous with justice is by no means universally accepted. See Weiner, supra note 50, at 132 ; CoOz, Princtples of Corporation Law (I925) 62I; Moulton, op. cit. supra note 6, at 360. 
dignity of an ultimate necessity under the conceptions of the progressive nature of the bankruptcy power and of due process as well, which permit the interpretation of powers and limitations to change to meet new and different conditions. Property rights generally, and even under the rather anomalous composition device, are not determined by democratic principles or majority control. Certainly there is nothing intrinsically indispensable about the vote of a certain, or any, percentage, especially where a business affected with a public interest is concerned and where so many of those voting on the reorganization plans can have little knowledge of the merits of the issues submitted to them. ${ }^{81}$

It is apparent also that, properly understood, the vote of interested parties on the fairness of a reorganization plan in a composition of creditors is purely advisory to the court. It is the court's action, not the vote, which is the force majeure. ${ }^{82}$ It is, therefore, reasonable and within the limits of the due process clause to substitute for the advisory arrangement heretofore employed, a more flexible procedure. ${ }^{83}$ The amended Act does this by providing that the affirmative advice, which has been heretofore required, may be replaced by a finding of the court that the

81 Cf. Friendly, Amendment of the Railroad Reorganization Act (I936) 36 Cor.

L. REv. 27,35 .

82 In Doty v. Love, 295 U. S. 64 (1935), which involved the constitutionality of a state statute permitting reorganization of insolvent banks where the reorganization plan had been approved by three fourths in amount of creditors and approved by the superintendent of banks and by the court, the Court said: "The creditors favoring reorganization, though they be ninety-nine percent, have no power under the statute to impose their will on a minority. They may advise and recommend, but they are powerless to coerce. Their recommendation will be ineffective unless approved by the superintendent. Even if approved by him, it will be ineffective unless the court, after a hearing, shall find it to be wise and just. Upon such a hearing every objection to the plan in point of law or policy may be submitted and considered. The decree when made by the Chancellor will represent his own unfettered judgment." 295 U. S. at 70-7I. It would seem that the purpose of the vote under such a statute is identical with that under the Bankruptcy Act. The mechanism of the two statutes is fundamentally similar, and no reason is perceived for distinguishing the function of the vote in one from the other. But $c f$. Matter of Title Mtge. \& Guar. Co., 264 N. Y. 69, I90 N. E. I53 (1934).

83 In making laws carrying into execution the powers vested by the Constitution in the Federal Government, Congress has a choice of means. It may use any means in fact conducive to the exercise of a power granted by the Constitution. United States v. Fisher, 2 Cranch 358, 396 (U. S. I805); M'Culloch v. Maryland, 4 Wheat. 316 (U. S. I8I9); In re Reimer, 20 Fed. Cas. No. II,673 (S. D. N. Y. I874). 
plan makes adequate provision for the treatment of the interests of those rejecting it and that their rejection is not reasonably justified in the light of the respective substantive rights of the rejecters. This seems a proper substitution especially where, as here, the plan has been recommended by an independent and informed administrative tribunal.

Some doubt has been expressed as to validity of the provisions under consideration ${ }^{84}$ as a result of the opinion of the Supreme Court in the case of Louisville Joint Stock Land Bank v. Radford ${ }^{85}$ in which it held unconstitutional the Frazier-Lemke Act, an opinion which was before the House committee when it approved the provisions in question. The Court held that the mortgagee could not be deprived by statute of his right to have the mortgaged property devoted primarily to the satisfaction of his debt either through receipt of the proceeds through a fair competitive sale, or by taking the property itself. The prohibition declared by the Court against the impairment of such rights was not absolute. In both the Radford case and in the Rock Island case, the Court recognized that the creditors can be deprived of such rights by a composition statute under which the dissenting creditors are bound where two thirds of the class have agreed to a plan and it has been found by the court to be fair and equitable. The amendments of Section 77 do not affect these rights in a different degree than the original Act.

In the Radford case the Court expressly held that the FrazierLemke Act was not a composition statute. That statute affected the debtor-creditor relationship between a farmer and the bank which held the mortgage on his farm. There was lacking the complexity and multiplicity characteristic of the typical railroad reorganization which create the procedural difficulties which have prompted the amendments here in question. As compared with that simple relationship, the pending Missouri Pacific reorganization involves property of great size, with eighty-four different kinds of indebtedness, seventeen mortgages, and seventy-two classes of interested parties. It is unnecessary to repeat here the considerations regarded as distinguishing the reorganization of

84 See Friendly, supra note $8 \mathrm{r}$, at 34 .

85295 U. S. 555 (I935). 
such a railroad from that of simple industrial or farm property. The denial of the right to a mortgage sale of a farm for a period of five years in the Radford case was the taking of a substantial zight which was essential to the preservation of the security afiorded by the mortgagee. The denial of the right to a foreclosure sale in a railroad reorganization is not such a taking. The elimination of the sale of the farm in the Radford case was part of a deliberate scheme on the part of Congress to cut down the substantive rights of mortgagees as a protection to a certain class of debtors in a time of great depression. These particular provisions of Section 77, as amended, are primarily procedural provisions, needed, on account of the multiplicity of claims arising in the reorganization of a complex property, in order that the substantive rights of the parties generally may be fully protected against imposition from obstructive minorities. ${ }^{86}$

The depression created the unmistakable necessity of a comprehensive reorganization statute. The maladministration of railroad reorganizations inevitably inclined Section 77 toward basic

86 In Tennessee Pub. Co. v. American Nat. Bank, 8I F.(2d) 463 (C. C. A. 6th, I936), the court held unconstitutional the provisions of subdivision (b) (5) of $\S 77 \mathrm{~B}$ providing for the confirmation of plans despite the disapproval of more than one third of a class of affected creditors where the plan provides adequate protection for the interests of dissenting creditors by appraisal and payment in cash of the value either of such interests or at the objecting creditor's election, of the securities, if any, allotted to such interests under the plan, or by such method as will in the opinion of the judge equitably provide such protection. The debtor, all of whose stock had been acquired by a single individual for the purpose of attempting a reorganization, presented a plan which was rejected by all the bondholders and by half of the general creditors. The property was appraised at less than $\$ 300,000$; the bonded indebtedness exceeded $\$ 900,000$; and the unsecured indebtedness exceeded $\$ 300,000$. Yet the plan provided that the debtor was to retain the property and that the objecting bondholders were to be paid the value of their interest in cash. What the unsecured creditors were to receive does not appear. The foregoing provisions of the statute were never intended for use where minor creditor classes or the shareholders attempt to force a plan on objecting major credit interests, and the court might well have dismissed the petition on that ground. (I936) 84 U. of PA. L. Rev. 780. The court held that these provisions were unconstitutional on the authority of the Radford decision, and with not thorough discussion of the problem. The considerations which are stated in the text with reference to the Radford case are equally applicable to this decision and are, it is believed, fully controlling. 
reforms, and toward a more active participation by the governmental agencies. This interposition was necessary in the protection of the investing public and of the railroads, as instrumentalities of interstate commerce, as well. It has occurred at a time when the dominant position held by the bankers in the reorganization of these properties is threatened by the public criticisms of their action in such reorganizations as that of the Milwaukee, the competition of the Reconstruction Finance Corporation in the field of railroad finance, the strict supervision of reorganization committees provided by the Securities and Exchange Act and by Section 77 itself, and the critical public attitude expressed by such public investigations of railroad activities of the bankers as have been conducted by the Securities and Exchange Commission and are now pending in the comprehensive inquiry being conducted by the Senate Committee on Interstate Commerce. These elements reflect a sensitive public interest and a changed public attitude. The banking concerns, as motivating factors in reorganizations, possessed a high effectiveness resulting from their excellent organization and from the driving processes permissible under the free play permitted by the accepted methods, the use of some of which have now been prevented; others, retarded. From a practical standpoint, if their activity is not to continue in its full measure, a substitute for its drive must be found, and a machinery must be established which will adequately meet the new necessities. In view of its duty to the public, if the government is to participate more directly in railroad reorganizations, it must do so with an efficiency commensurate with a responsibility deliberately undertaken. The most difficult aspect of a regulatory and administrative problem of this type lies in the fact that the governmental interference, established to correct abuses arising from the uncontrolled efficiency of private initiative, is apt to create an inefficiency fully as harmful as the abuses. This frequently is the consequence of that ineffectiveness of the democratic process which results from the multiplicity of counsel and authority which is apparently one of the essentials of the process itself. In the administration of this statute, that inefficiency may arise in part through the unavoidable necessity of the duality of administration by both the Commission and the courts. This 
duality will destroy the effectiveness of the statute only if the Commission and the courts fail to rise to the demand of that high administrative intelligence which the difficult work requires. To accomplish these reorganizations successfully, these agencies must have the intelligent and active support of the creditors and stockholders. Reorganization plans for properties of such complexity and magnitude are to be best accomplished not by the imposition by the government, but by its mediation. How these governmental agencies can administer a law, designed to prevent abuses from the exercise of private initiative, in a manner not to destroy, but to sustain, that initiative, is again the old and difficult problem of the golden mean. This is not something to be written into a statute. It lies in the wisdom of its administrators. Against the failure of the personal equation in the administration of the law, no provision of the law will protect.

Leslie Craven. Warner Fuller.

WASHINGTON, D. C.

Duke UntyerstTy School of Law. 